\title{
A Critical Reading Process on Foreign Language Pedagogical Knowledge: Toward a Developmental Theory of Beginning Teacher Practices (The Abstract Text of A Research Paper in The Modern Language Journal)
}

\author{
Oleh: \\ Feni Munifatullah \\ English Education Study Program \\ Department of Language and Arts Education \\ Faculty of Teacher Training and Education University of Lampung \\ Email:fenimunifa@gmail.com
}

\begin{abstract}
This article discusses the abstract of the paper entitled Foreign Language Pedagogical Knowledge: Toward a Developmental Theory of Beginning Teacher Practices in The Modern Language Journal 91(07):63-82 from critical thinking standards and critical literacy supported by systemic functional grammar aspects. The analyses indicate that the text can be considered as an appropriate text considering the author, its audience, its wellestablished and complete structure, and a very concise purpose. The text is clear, accurate, relevant, broad, and sufficient. It is consistent to what it discusses along the text, provides the facts instead of opinions, and contains so many topics but lacks cohesive devices. Besides, the critical literacy aspects guide the reader to explore deeper into the text by using systemic functional grammar some aspect of cohesion is solved by theme progression and the use of tenses and modals. The discussion has assisted the reader to come to a conclusion that the abstract is well presented/produced.
\end{abstract}

Keywords: critical thinking standards, critical thinking literacies, functional analysis 


\section{INTRODUCTION}

This article explores an abstract of a research article to the extent that the Paul \& Elder's (2013) critical thinking standards and Halliday's functional linguistics are employed. In the first place, critical skill standards are used to discuss the context of the chosen text regarding its author, audience, structure, its place in the society and the topic. The functions and purposes of the text will also be analyzed for its clarity, accuracy, relevance, sufficiency, precision, depth and breadth. Including in this context is the inter-textuality and its relation to the personal experience of the reader and to the world paradigm. When the context has been analyzed carefully from its critical point of view, the article's focus will move to the discussion of the chosen text based on critical literacy theory using systemic functional linguistic aspects. Therefore the text' characteristics emerge from the text's cohesion from themes and theme progression and process which will involve participants and processes in the text. The elements are discussed to show how appropriate the text is when it represents the meaning of the text.

\section{ANALYSIS OF THE TEXT}

The analysis is divided into three subsections based on the parameters adopted as the framework of the study. The text is randomly chosen within a specific domain of academic discourse.

\section{THE CONTEXT}

The writer of the text can be a researcher on professional development, a teacher educator, a member of teacher education assessor board, teacher trainer, a teacher mentor or coach, or an experienced teacher. The audience could be the academic society, consisting of various members such as researchers on English language teaching, teacher professional development, teacher professional developer/trainer, English teachers, and the members of policymaker board for teacher education and development, and/or linguists who are interested in researching the English language teaching. The text is originally written as a short description of a research report article. If the paragraphs are published in a different mode of publication, the text could be written in a different writing genre by employing a simpler word choice and a more flexible structure. Thus, the text can be published in a popular magazine or newspaper and the result of the study can be comprehended by a more general audience.

\section{THE FUNCTIONS: THE THEMES PROGRESSION}

The text is an abstract about the development of foreign language pedagogical knowledge in teaching practice. An abstract is a summary of the text and it informs readers of what can be found in the dissertation (or research report) and in what order, functioning as an overall signpost for the reader (Cooley and Lewkowicz in Paltridge (2007)). It is generally the part which a reader will firstly look at. The abstract typically aims to provide an overview of the study which answers the questions of the general purpose of the study, a particular aim of the study, and the reason why the study was carried out. Swales (1990) states that an abstract 
provides the introduction to the content of the paper at the same time it functions as the summary. The introductory function is a news value which occurs because it is an advance indicator of the content and the structure of the following text while the summary matter is representation values for the abstract considers the article as a whole.

Based on the definitions in the previous paragraph, the abstract performs an introductory function and a summary function. In the introductory function, the abstract introduces three new information in three sentences; the first, the fourth and the final sentence. The first sentence: This longitudinal study focuses on how pedagogical content knowledge is initially represented and changes during the beginning teaching experiences of 9 teachers of French, German, and Spanish, introduces the focus of the paper. The fourth sentence: Four core categories-prior knowledge that frames instructional decisions, attitudes toward teacher control in the classroom, instructional goals for daily lessons, and considerations for responding to student affect-were identified to explain an overarching change in foreign language pedagogical content knowledge, indicates the findings. And the last sentences recommend something from the study; Professional development of beginning teachers must support the ongoing transformation of pedagogical content knowledge in order to ensure that these early characteristics do not become lasting traits in long-term teaching careers.

On the other side, in performing the summary function, the text is tight and condensed to the extent that it represents the whole content of the paper. Comparing to the complete paper it represents/summarizes, this text only uses seven sentences to describe the content. The sentences are broken down into eight clauses which mostly are dependent ones. For example the sentence below.

This longitudinal study focuses on [[how pedagogical content knowledge is initially represented and changes during the beginning teaching experiences of 9 teachers of French, German, and Spanish.]]

The sentence consists of a dependent clause [[how pedagogical content knowledge is initially represented and changes during the beginning teaching experiences of 9 teachers of French, German, and Spanish.]] to represent the main goal of the processes of the whole article. The author's uses of complex sentences can be interpreted as an effort of presenting the summary because it minimizes the length but reaches the breadth. Furthermore, the summary is indicated by the schematic structure of the abstract.

Swales (1990) indicates the pattern of abstract as the reflection of the research article structure, the Introduction ${ }^{\wedge}$ Method $^{\wedge}$ Results $^{\wedge}$ Discussion. Emilia (2008) writes that Hyland finds the most typical rhetorical moves in an academic article that he analyzed are Purpose ${ }^{\wedge}$ Method ${ }^{\wedge}$ Product. Adnan (2002) and Hardjanto in Adnan (2002) uses a different model to explain the stages in an abstract. The stages are Creating A Research Space(CARS)^Explaining Research Procedures ${ }^{\wedge}$ Summarize the Findings ${ }^{\wedge}$ Evaluate the Results. Paltridge (2007) suggests five moves for abstract, they are Overview of study^Aim of Study ${ }^{\wedge}$ Reason for the Study^Methodology^Findings. As far as it is observed, the abstract 
consists of Aims of the Study/Overview of the Study/Creating Research Space/Introduction ${ }^{\wedge}$ Method/Explaining Research Procedures ${ }^{\wedge}$ Method/Methodology ${ }^{\wedge}$ Result/(Summarize the) Findings ${ }^{\wedge}$ Discussion ${ }^{\wedge}$ Discussion ${ }^{\wedge}$ Recommendation/Evaluate the Result (see appendix 2).

There are four parts in the structure of the abstract. Each part of the structure is marked by different topic reflecting its theme. The themes for the aims of the study are his longitudinal study and pedagogical content knowledge as the topical themes and "how" as a textual theme.

Following the first part of the abstract, there are two topical themes for methods (the second part of the structure), i.e. the data and the grounded theory design. The resulting move consists of a topical theme. Four core categories which are elaborated and mentioned in its dependent clause as prior knowledge, attitudes toward teacher control in the classroom, instructional goals for daily lessons, and considerations for responding to student affect. All sentences provide topical marked themes.

The results are the next marked topical theme for the Discussion moves (the third part of the abstract). It is followed by some themes under the embedded clause explaining the word proportion. The 'approaches instruction 'theme is the theme which explains the word proportion, and it is elaborated by a textual theme such as followed by examples of the approaches, i.e. communicative language teaching, and their related theoretical underpinnings in language learning, Only in this part that the text shows a connection between two sentences; indicated by replacing the phrase four core categories with the results. Therefore, it can be stated that there is a theme progression between the result and discussion move.

The next discussion move is started by a marked topical theme. Similar to research findings in other subject disciplines, another marked theme in the part "the instructional practices of beginning FL teachers" signifies a stop on theme progression that has been seen before. The researcher, then, marks two constructs, control over students and the instructional content to categorize the results as larger themes which he considers to serve as a proxy for perceptions of successful teaching.

Finally, he recommends by supplying a new unmarked theme Professional development of beginning teachers and he, again mention these early characteristics to replace the constructs which he mentioned before. In conclusion, there are two parts of the text that show theme progression, i.e. between the result and discussion moves, and between discussion and recommendation moves. To have a clearer description of themes, a theme progression chart is supplied here. 
AKSARA Jurnal Bahasa dan Sastra

Vol. 18, No. 2, Hal. 154 - 168, Oktober 2017

http://jurnal.fkip.unila.ac.id/index.php/aksara

\section{THEME PROGRESSION}

This longitudinal study focuses on

Topical theme

how pedagogical content knowledge

is initially represented and changes during the beginning teaching experiences of 9 teachers of French, German, and Spanish.

textual topical (multiple) theme RHEME

\section{The data consist of}

reflective journal entries,

classroom observations,

and focus group interviews

Topical theme (is) collected during the first 2 years of foreign language

(FL) teaching at the high school level.

RHEME

Techniques of grounded theory analysis were used to develop a theoretical framework topical theme comprehensive to the data.

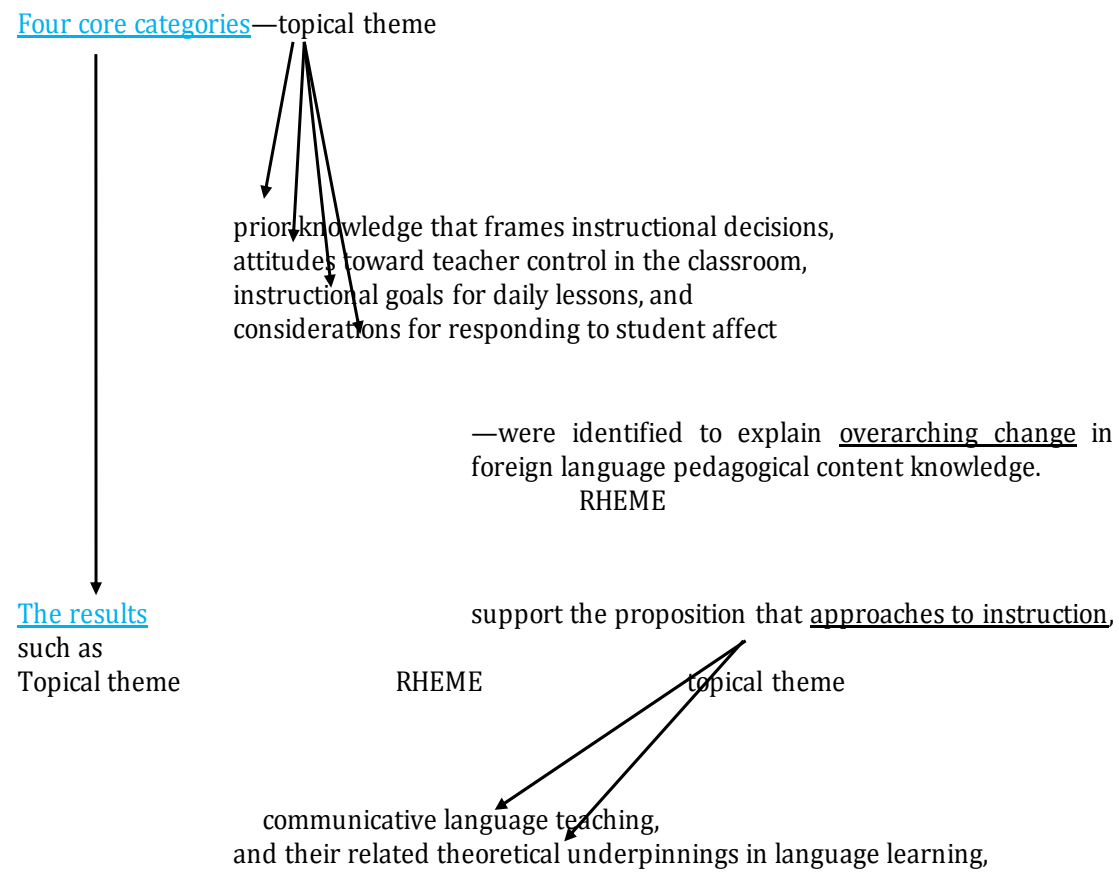

develop as pedagogical content knowledge through a process of teaching, conflict, reflection, and resolution specific to the in-service classroom context.

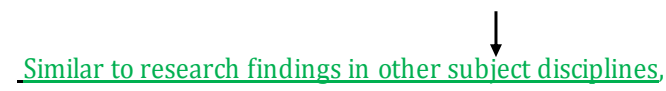

Marked topical theme

the instructional practices of beginning FL teacher

marked topical theme may initially be considered traditional, outdated, or even antithetical to their preservice preparation RHEME 
The structure of the themes also shows that the text has a hyper theme in the first sentence but the themes change from one sentence to the next. Even the method sections/moves are quite difficult to connect to each other. In spite of the quick change of the themes, the text shows that the writer is successful in providing relevant sentences. The researcher is absent in the abstract to avoid subjectivity of the result. The researcher is replaced by some abstract nouns such as "this longitudinal study", "the data", "techniques" and much more, which play a role as the participants in most clauses. Therefore, the position of the writer cannot be seen from the text either his/her interpersonal aspects. Even the text lacks textual themes. The connection from one sentence to another is shown by very few uses of related words.

\section{THE FUNCTIONS: CLAUSE PROCESSES}

Having discussed the critical literacy aspects (related to the author, audience, and its comparison to other text in the same type in its structure, topic, and content), critical thinking standards (clarity, accuracy, relevance, sufficiency, precision, length and depth), and the final aspect to discuss is the type of processes of each clause to complete the analysis of the text. The processes are summarized in the following table:

Table. 1 Summary of Text Processes

\begin{tabular}{|l|l|l|l|l|l|l|l|}
\hline $\begin{array}{l}\text { Process } \\
\text { Types }\end{array}$ & Material & Mental & Verbal & Intensive & $\begin{array}{l}\text { Circ.Cause, } \\
\text { and } \\
\text { Possessive }\end{array}$ & Behavior & $\begin{array}{l}\text { Exist/Relat } \\
\text { ional }\end{array}$ \\
\hline Total & 9 & 3 & - & - & 9 & - & 3 \\
\hline
\end{tabular}

There are two ideas which are implied through the type of process in the text. The dominant amount of material processes in the text shows that the processes confirm there are actors and the recipients for them. The considerable point is that the actors are abstract nouns and the goals or ranges are the effects which are taken into account. Thus, the writer intends to replace the real actors with the abstract nouns. The material processes show that most of the activity is done with the intention to achieve certain goals. The relational process is shown in stating the data types and the results as it is stating the existence. The mental process verbs are used in the latter part of the text, starting from the sentence which shows discussion of the result up to the recommendation.

Since the text is dense and full of material processes done by abstract nouns, the analysis of the text shows that complex sentences are highly accurate. To add the process analysis, an elaboration to mood aspect is done. The mood system can be seen from this chart.

There are twelve subjects followed by 15 predicators because some of the predicators have the same subjects. The use of past and present are both available. Although this is, to some extent, contradictory, the place of past tenses is in the former part. Past tense is used to show the data collection procedure and the results. Most of the sentences use the present tense. According to Cooley and Lewkowicz in Paltridge (2007), it means that the paper is a (part of) dissertation or thesis as it has been mentioned before. There are two modals found in the 
text, i.e. the words may and must. The first has the low level of polarity while the second is high. The use of low-level polarity signifies the author's disagreement with the statement because he supplies opposite arguments on the next sentence. Using the modal must the author emphasizes his demand for the development of professional development activities for beginning teachers. The last sentence shows that it is a statement but demanding something to do with anyone in charge.

...the instructional practices of beginning FL teachers may initially be considered traditional, outdated, or even antithetical to their preservice preparation as control over students and the instructional content serve as a proxy for perceptions of successful teaching.

Professional development of beginning teachers must support the ongoing transformation of pedagogical content knowledge in order to ensure that these early characteristics do not become lasting traits in long-term teaching careers.

\section{DISCUSSION}

Comparing to several other abstracts written for the similar topic, it is found that the structures are not identical. There is an abstract which does not have a very crucial and important "Method" part. There are other abstracts which can be understood more easily, but some are more "jumping" in sequencing their themes. In the chosen abstract, the writer connects the first sentence with the title, showing the most important idea which is brought by the sentence. Therefore, the text in the analysis can be considered as more complete and serves its purpose. Besides, each move labeled for an abstract is available in this text so that it is complex and complete as well. Comparing to the reader experience, she ever wrote abstracts which have a longer section for CARS but imply no grammatical metaphors in the end of the abstract.

The use of present tense in the text is in line with what has been proposed by Geertz in Swales (1990) that abstract is written in tightly worded sentences. According to Cooley and Lewkowicz in Paltridge (2007), as a summary of their thesis or dissertation, the author of the abstract will typically use the present simple tense. Therefore, the abstract and the article it represents is assumed as a dissertation or thesis report. However, the tense in the text is contradictory with Gaertz (in Swales, 1990) who characterizes the language of abstract as the use of past tense, third person, passive, and the non-use of negatives. It avoids subordinate clauses, uses phrases instead of clauses, words instead of phrases....but the text fits Geertz's criteria of redundancies elimination. The abstract is well supplied by specific and precise facts based on the study. The use of words "four core categories were identified" shows high precision. The text is not deep but broad enough to cover the limit of the research but it is understandable because it is just an abstract. The breadth of the text can be identified from its multiple layers of the sentence. 
For example:

a. This longitudinal study focuses on [[how pedagogical content knowledge is initially represented and changes during the beginning teaching experiences of 9 teachers of French, German, and Spanish.]]a

b. Four core categories were identified - prior knowledge that frames instructional decisions, attitudes toward teacher control in the classroom, instructional goals for daily lessons, and considerations for responding to student affect- [[to explain overarching change in foreign language pedagogical content knowledge.]]a

c. Similar to research findings in other subject disciplines, the instructional practices of beginning FL teachers may initially be considered traditional, outdated, or even antithetical to their preservice preparation [[as control over students and the instructional content serve as a proxy for perceptions of successful teaching.]]a

Those three sentences have wrapped up many important points in different layers to cover the topic of the study and the specific aim of the study (sentence a), the findings in general and details (sentence b), and discussion to the extent that the text compares the result with other findings and the constructs that are found. Regarding its clarity, the complex sentences do not leave ambiguous interpretation to the reader. They focus only on the information related to the study and use words which are most frequently used and familiar to in research article reasoning. The text is clear as it is based on observation. The writer has a high level of certainty of what he/she has done as she/he puts a grammatical metaphor at the end of the text. In spite of its complexity, the text can also be considered as having relevant and sufficient content. However, to get deeper information someone has to go to the complete form of the paper.

\section{CONCLUSION}

This article explores an abstract of a research article using critical skill standard and critical literacy. In the first place, critical skill standards are used to discuss the context of the chosen text regarding its author, audience, structure, its place in the society and the topic. The functions and purposes of the text will also be analyzed for its clarity, accuracy, relevance, sufficiency, precision, depth and breadth. Including in this context is the inter-textuality and its relation to the personal experience of the reader and to the world paradigm. When the context has been analyzed carefully from its critical point of view, the article's focus will move to the discussion of the chosen text based on critical literacy theory using systemic functional linguistic aspects. Therefore, the text' characteristics emerge from the text's cohesion from themes and theme progression and process which will involve participants and processes in the text. The elements are discussed to show how appropriate the text is when it represents the meaning of the text.

By discussing the text from critical thinking standards and critical literacy supported by systemic functional grammar aspects, there are several conclusions which can be drawn. The first one, from critical thinking standards the text can be considered as an appropriate text for considering who the author is, its own audience, well-established and complete in its 
structure, and very concise for its purposes as an analytical text suggesting a follow-up action. How it is compared to the proposed structure and criteria from experts in academic writing and also the personal experience of the reader is also displayed. The text is clear, accurate, relevant, broad, and sufficient. It is consistent to what it discusses along the text, it provides facts instead of opinions, and it contains so many topics but lacks cohesive devices. The second one, the critical literacy aspects guides the reader to explore deeper into the text by using systemic functional grammar some aspect of cohesion is solved by theme progression and the use of tenses and modals. The discussion has explored the topic of the text including its theme in sentence/clause and paragraph level. By examining those aspects and applying critical thinking standards and skills, the reader can come to a conclusion that the abstract is well presented/produced.

\section{REFERENCES}

Adnan, Z\&Zilfirdaus, I. 2002. Merebut Hati Audiens Internasional; Strategi Jitu Meraih Publikasi di Jurnal Ilmiah.(2nd edition). MLI. Jakarta

Emilia, Emi. 2008. Menulis Tesis dan Disertasi.ALFABETA. Bandung 2005. A Critical Genre-Based Approach to Teaching Academic Writing in Tertiary EFL Context in Indonesia. A doctoral dissertation.

Humphrey,S. \& Dorga,L. 2003. Grammar and Meaning; A Introduction for Primary Teachers. Target Texts. New South Wales.

Martin,J.R.,\&Matthiesen,C.M.I.M\&Painter, C. 1997. Working with Functional Grammar. Arnold. New York.

Martin,J.R.\&Rose,D. 2003. Working with Discourse;Meaning Beyond the Clause. Continuum. London

Gerot,L\&Wignell, 1994. Making Sense of Functional Grammar; An Introductory Workbook.Gerd Stabler Antipodean Education Enterprises. Sydney

Paltridge, B\&Starfield, S. 2007. Thesis and Dissertation Writing in a Second Language; a Handbook for Supervisors. Routledge. London

Paul, R., \& Elder, L. 2013. Critical thinking: intellectual standards essential to reasoning well within every domain of human thought, part two. Journal of Developmental Education, 32-36.

Swales, J. M. 1990. Genre analysis; English in Academic and research settings . Melbourne: Cambridge.

Watzke, S. 2007. Foreign Language Pedagogical Knowledge: Toward a Developmental Theory of Beginning Teacher Practices. In The Modern Language Journal 91(07):6382. 


\section{APPENDIX 1. The Text}

This longitudinal study focuses on how pedagogical content knowledge is initially represented and changes during the beginning teaching experiences of 9 teachers of French, German, and Spanish. The data consist of reflective journal entries, classroom observations, and focus group interviews collected during the first 2 years of foreign language (FL) teaching at the high school level. Techniques of grounded theory analysis were used to develop a theoretical framework comprehensive to the data. Four core categories-prior knowledge that frames instructional decisions, attitudes toward teacher control in the classroom, instructional goals for daily lessons, and considerations for responding to student affect-were identified to explain overarching change in foreign language pedagogical content knowledge. The results support the proposition that approaches to instruction, such as communicative language teaching, and their related theoretical underpinnings in language learning, develop as pedagogical content knowledge through a process of teaching, conflict, reflection, and resolution specific to the in-service classroom context. Similar to research findings in other subject disciplines, the instructional practices of beginning FL teachers may initially be considered traditional, outdated, or even antithetical to their preservice preparation as control over students and the instructional content serve as a proxy for perceptions of successful teaching. Professional development of beginning teachers must support the ongoing transformation of pedagogical content knowledge in order to ensure that these early characteristics do not become lasting traits in long-term teaching careers. 


\section{APPENDIX 2. CLAUSES IN THE TEXT}

\begin{tabular}{|c|c|c|}
\hline No & Sentence & Clause(s) \\
\hline \multirow[t]{2}{*}{1} & \multirow{2}{*}{$\begin{array}{l}\text { This longitudinal study focuses on [[how } \\
\text { pedagogical content knowledge is initially } \\
\text { represented and changes during the } \\
\text { beginning teaching experiences of } 9 \text { teachers } \\
\text { of French, German, and Spanish.]] }\end{array}$} & 1.This longitudinal study focuses on \\
\hline & & $\begin{array}{l}\text { 1a.. how pedagogical content knowledge is } \\
\text { initially represented and changes during } \\
\text { the beginning teaching experiences of } 9 \\
\text { teachers of French, German, and Spanish. }\end{array}$ \\
\hline 2 & $\begin{array}{l}\text { The data consist of reflective journal entries, } \\
\text { classroom observations, and focus group } \\
\text { interviews a collected during the first } 2 \text { years } \\
\text { of foreign language (FL) teaching at the high } \\
\text { school level. }\end{array}$ & $\begin{array}{l}\text { 2. The data consist of reflective journal } \\
\text { entries, classroom observations, and focus } \\
\text { group interviews } 2 \text { a. collected during the } \\
\text { first } 2 \text { years of foreign language (FL) } \\
\text { teaching at the high school level. }\end{array}$ \\
\hline \multirow[t]{2}{*}{3} & \multirow{2}{*}{$\begin{array}{l}\text { Techniques of grounded theory analysis were } \\
\text { used } \\
\text { [[to develop a theoretical framework } \\
\text { comprehensive to the data ]]a }\end{array}$} & $\begin{array}{l}\text { 3. lecnmiques or grounded theory anarysis } \\
\text { were used }\end{array}$ \\
\hline & & $\begin{array}{l}\text { 3a.to develop a theoretical framework } \\
\text { comprehensive to the data framework } \\
\text { comprehensive to the data. }\end{array}$ \\
\hline \multirow[t]{2}{*}{4} & \multirow{2}{*}{$\begin{array}{l}\text { Four core categories were identified - prior } \\
\text { knowledge that frames instructional } \\
\text { decisions, attitudes toward teacher control in } \\
\text { the classroom, instructional goals for daily } \\
\text { lessons, and considerations for responding to } \\
\text { student affect- [[to explain overarching } \\
\text { change in foreign language pedagogical } \\
\text { content knowledge.]]a }\end{array}$} & $\begin{array}{l}\text { 4.Four core categories were identified - } \\
\text { prior knowledge that frames instructional } \\
\text { decisions, attitudes toward teacher control } \\
\text { in the classroom, instructional goals for } \\
\text { daily lessons, and considerations for } \\
\text { responding to student affect- }\end{array}$ \\
\hline & & $\begin{array}{l}\text { tange in foreign } \\
\text { t knowledge }\end{array}$ \\
\hline \multirow[t]{2}{*}{5} & \multirow[b]{2}{*}{$\begin{array}{l}\text { The results support the proposition [[that } \\
\text { approaches to instruction, such as } \\
\text { communicative language teaching, } \\
\text { and their related theoretical underpinnings in } \\
\text { language learning, develop as pedagogical } \\
\text { content knowledge through a process of } \\
\text { teaching, conflict, reflection, and resolution } \\
\text { specific to the in-service classroom } \\
\text { context.]la }\end{array}$} & \\
\hline & & $\begin{array}{l}\text { 5a. That approaches to instruction, such as } \\
\text { communicative language teaching, and their } \\
\text { related theoretical underpinnings in } \\
\text { language learning develop content } \\
\text { knowledge through a process of teaching, } \\
\text { conflict, reflection, and resolution specific to } \\
\text { the in-service classroom context. }\end{array}$ \\
\hline \multirow[t]{2}{*}{6} & \multirow{2}{*}{$\begin{array}{l}\text { Similar to research findings in other subject } \\
\text { disciplines, } \\
\text { the instructional practices of beginning FL } \\
\text { teachers may initially be considered } \\
\text { traditional, } \\
\text { outdated, or even antithetical to their } \\
\text { preservice preparation [[as control over } \\
\text { students and } \\
\text { the instructional content serve as a proxy for } \\
\text { perceptions of successful teaching.]] }\end{array}$} & $\begin{array}{l}\text { 6. Similar to research findings in other } \\
\text { subject disciplines, the instructional } \\
\text { practices of beginning FL teachers may } \\
\text { initially be considered traditional, } \\
\text { outdated, or even antithetical to their } \\
\text { preservice preparation }\end{array}$ \\
\hline & & $\begin{array}{l}\text { 7. as control over students and } \\
\text { the instructional content serve as a proxy } \\
\text { for perceptions of successful teaching. }\end{array}$ \\
\hline
\end{tabular}


AKSARA Jurnal Bahasa dan Sastra

Vol. 18, No. 2, Hal. 154 - 168, Oktober 2017

http://jurnal.fkip.unila.ac.id/index.php/aksara

\begin{tabular}{|c|c|c|}
\hline 7 & $\begin{array}{l}\text { Professional } \\
\text { development of beginning teachers must } \\
\text { support the ongoing transformation of } \\
\text { pedagogical }\end{array}$ & $\begin{array}{l}\text { 8.Professional development of beginning } \\
\text { teachers must support the ongoing } \\
\text { transformation of pedagogical content } \\
\text { knowledge in order to ensure }\end{array}$ \\
\hline & $\begin{array}{l}\text { content knowledge in order to ensure that } \\
\text { these early characteristics do not become } \\
\text { lasting } \\
\text { traits in long-term teaching careers. }\end{array}$ & $\begin{array}{l}\text { 8a.that these early characteristics do not } \\
\text { become lasting traits in long-term teaching } \\
\text { careers }\end{array}$ \\
\hline
\end{tabular}

\section{APPENDIX 3. ORGANIZATION OF THE TEXT}

\begin{tabular}{|c|c|c|}
\hline No & Structure & Sentences \\
\hline 1 & Purpose & $\begin{array}{l}\text { This longitudinal study focuses on [[how } \\
\text { pedagogical content knowledge is initially } \\
\text { represented and changes during the beginning } \\
\text { teaching experiences of } 9 \text { teachers of French, } \\
\text { German, and Spanish.]] }\end{array}$ \\
\hline 2 & Method & $\begin{array}{l}\text { The data consist of reflective journal entries, } \\
\text { classroom observations, and focus group interviews } \\
\text { a collected during the first } 2 \text { years of foreign } \\
\text { language (FL) teaching at the high school level. }\end{array}$ \\
\hline 3 & Method & $\begin{array}{l}\text { Techniques of grounded theory analysis were used } \\
\text { [[to develop a theoretical framework } \\
\text { comprehensive to the data ]]a }\end{array}$ \\
\hline 4 & Result & $\begin{array}{l}\text { Four core categories were identified -prior } \\
\text { knowledge that frames instructional decisions, } \\
\text { attitudes toward teacher control in the classroom, } \\
\text { instructional goals for daily lessons,[and } \\
\text { considerations for responding to student affect- } \\
\text { [[to explain overarching change in foreign language } \\
\text { pedagogical content knowledge.]]a }\end{array}$ \\
\hline 5 & Discussion & $\begin{array}{l}\text { The results support the proposition [[that } \\
\text { approaches to instruction, such as communicative } \\
\text { language teaching, } \\
\text { and their related theoretical underpinnings in } \\
\text { language learning, develop as pedagogical content } \\
\text { knowledge through a process of teaching, conflict, } \\
\text { reflection, and resolution specific to the in-service } \\
\text { classroom context.]]a }\end{array}$ \\
\hline
\end{tabular}


AKSARA Jurnal Bahasa dan Sastra

Vol. 18, No. 2, Hal. 154 - 168, Oktober 2017

http://jurnal.fkip.unila.ac.id/index.php/aksara

\begin{tabular}{|l|l|l|}
\hline 6 & Discussion & $\begin{array}{l}\text { Similar to research findings in other subject } \\
\text { disciplines, } \\
\text { the instructional practices of beginning FL teachers } \\
\text { may initially be considered traditional, outdated, or } \\
\text { even antithetical to their preservice preparation } \\
\text { [[as control over students and the instructional } \\
\text { content serve as a proxy for perceptions of } \\
\text { successful teaching.] }\end{array}$ \\
\hline 7 & $\begin{array}{l}\text { Conclusion?Recommen } \\
\text { dation?Evaluating the } \\
\text { Result }\end{array}$ & $\begin{array}{l}\text { Professional development of beginning teachers } \\
\text { must support the ongoing transformation of } \\
\text { pedagogical these } \\
\text { content knowledge in order to ensure that these } \\
\text { early characteristics do not become lasting } \\
\text { traits in long-term teaching careers. }\end{array}$ \\
\hline
\end{tabular}

\section{APPENDIX 4. THEME PROGRESSION}

\begin{tabular}{|c|c|c|c|c|}
\hline \multirow[t]{2}{*}{ Textual } & \multicolumn{2}{|l|}{ Topical } & \multirow[t]{2}{*}{ Interpersonal } & \multirow[t]{2}{*}{ Rheme } \\
\hline & Marked & Unmarked & & \\
\hline- & $\begin{array}{l}\text { This longitudinal } \\
\text { study }\end{array}$ & - & - & focuses on \\
\hline How & & $\begin{array}{l}\text { pedagogical } \\
\text { content } \\
\text { knowledge }\end{array}$ & & $\begin{array}{l}\text { is initially represented } \\
\text { and changes..., and } \\
\text { Spanish. }\end{array}$ \\
\hline \multirow[t]{6}{*}{-} & The data & - & - & $\begin{array}{l}\text { (is)collected during the } \\
\text { first } 2 \text { years of foreign } \\
\text { language (FL) teaching at } \\
\text { the } \\
\text { high school level. }\end{array}$ \\
\hline & The data & & & consist of........ \\
\hline & & $\begin{array}{l}\text { Techniques of } \\
\text { grounded theory } \\
\text { analysis }\end{array}$ & & were used \\
\hline & & $\begin{array}{l}\text { Techniques of } \\
\text { grounded theory } \\
\text { analysis }\end{array}$ & & $\begin{array}{l}\text { to develop a [[theoretical } \\
\text { framework } \\
\text { comprehensive to the } \\
\text { data]] }\end{array}$ \\
\hline & $\begin{array}{l}\text { Four core } \\
\text { categories- } \\
\text { [[prior } \\
\text { knowledge that } \\
\text { frames } \\
\text { instructional } \\
\text { decisions, } \\
\text { attitudes toward } \\
\text { teacher control } \\
\text { in the classroom, } \\
\text { instructional } \\
\text { goals for daily } \\
\text { lessons, and } \\
\text { considerations } \\
\text { for responding } \\
\text { to student } \\
\text { affect]]- }\end{array}$ & & & $\begin{array}{l}\text { were identified to } \\
\text { explain overarching } \\
\text { change in foreign } \\
\text { language pedagogical } \\
\text { content knowledge. }\end{array}$ \\
\hline & The results & & & $\begin{array}{l}\text { support the proposition } \\
\text { [[that approaches to }\end{array}$ \\
\hline
\end{tabular}


AKSARA Jurnal Bahasa dan Sastra

Vol. 18, No. 2, Hal. 154 - 168, Oktober 2017

http://jurnal.fkip.unila.ac.id/index.php/aksara

\begin{tabular}{|c|c|c|c|}
\hline & & & $\begin{array}{l}\text { instruction, such as } \\
\text { communicative language } \\
\text { teaching, and their } \\
\text { related theoretical } \\
\text { underpinnings in } \\
\text { language learning]], } \\
\text { develop as pedagogical } \\
\text { content knowledge } \\
\text { through a process of } \\
\text { teaching, conflict, } \\
\text { reflection, and resolution } \\
\text { specific to the in-service } \\
\text { classroom context. }\end{array}$ \\
\hline & $\begin{array}{l}\text { approaches to } \\
\text { instruction (such } \\
\text { as } \\
\text { communicative } \\
\text { language } \\
\text { teaching, and } \\
\text { their related } \\
\text { theoretical } \\
\text { underpinnings } \\
\text { in language } \\
\text { learning) }\end{array}$ & & $\begin{array}{l}\text { develop as pedagogical } \\
\text { content knowledge } \\
\text { through a process of } \\
\text { teaching, conflict, } \\
\text { reflection, and resolution } \\
\text { specific to the in-service } \\
\text { classroom context. }\end{array}$ \\
\hline & $\begin{array}{l}\text { Similar to } \\
\text { research } \\
\text { findings in other } \\
\text { subject } \\
\text { disciplines }\end{array}$ & & \\
\hline & $\begin{array}{l}\text { the instructional } \\
\text { practices of } \\
\text { beginning FL } \\
\text { teachers }\end{array}$ & & $\begin{array}{l}\text { may initially be } \\
\text { considered traditional, } \\
\text { outdated, or even } \\
\text { antithetical to their } \\
\text { preservice preparation }\end{array}$ \\
\hline \multirow[t]{2}{*}{ As } & & $\begin{array}{l}\text { control over } \\
\text { students and the } \\
\text { instructional } \\
\text { content }\end{array}$ & $\begin{array}{l}\text { serve as a proxy for } \\
\text { perceptions of successful } \\
\text { teaching. }\end{array}$ \\
\hline & & $\begin{array}{l}\text { Professional } \\
\text { development of } \\
\text { beginning } \\
\text { teachers }\end{array}$ & $\begin{array}{l}\text { must support the } \\
\text { ongoing transformation } \\
\text { of pedagogical content } \\
\text { knowledge }\end{array}$ \\
\hline \multirow[t]{2}{*}{ in order } & & To ensure & \\
\hline & $\begin{array}{l}\text { these early } \\
\text { characteristics }\end{array}$ & & $\begin{array}{l}\text { do not become lasting } \\
\text { traits in long-term } \\
\text { teaching careers. }\end{array}$ \\
\hline
\end{tabular}

\section{APPENDIX 5.PROCESSES IN THE TEXT}

This longitudinal study focuses on how pedagogical content knowledge is initially represented and

changes during the beginning teaching experiences of 9 teachers of French, German, and Spanish.

The data (is) collected during the first 2 years of foreign language (FL) teaching at the high school level.

The data consist of reflective journal entries, classroom observations, and focus group interviews 
AKSARA Jurnal Bahasa dan Sastra

Vol. 18, No. 2, Hal. 154 - 168, Oktober 2017

http://jurnal.fkip.unila.ac.id/index.php/aksara

Techniques of grounded theory analysis were used

to develop a theoretical framework comprehensive to the data.

Four core categories - prior knowledge that frames instructional decisions, attitudes toward teacher control in the classroom, instructional goals for daily lessons, and considerations for responding to student affect-were identified to explain overarching change in foreign language pedagogical content knowledge.

The results support the proposition that

approaches to instruction, such as communicative language teaching, and their related theoretical underpinnings in language learning, develop as pedagogical content knowledge through a process of teaching, conflict, reflection, and resolution specific to the in-service classroom context.

Similar to research findings in other subject disciplines, the instructional practices of beginning FL teachers may initially be considered traditional, outdated, or even antithetical to their preservice preparation

as control over students and the instructional content serve as a proxy for perceptions of successful teaching.

Professional development of beginning teachers must support the ongoing transformation of pedagogical content knowledge in order to ensure that these early characteristics do not become lasting traits in long-term teaching careers.

$\begin{array}{ll}\text { Red } & : \text { material processes } \\ \text { Orange } & \text { : relational process } \\ \text { Green } & \text { : circumstances } \\ \text { Blue } & : \text { mental }\end{array}$

